\title{
Business union vs. business union? Understanding the split in the US labour movement
}

\author{
Ian Greer
}

In summer 2005, the trade union movement formalised its split into two rival confederations. The split was precipitated by the 2001 disaffiliation of the carpenters' union, the Republican electoral victory of 2004, and the decline in union membership. Seven unions, accounting for forty per cent of the membership of the AFL-CIO formed Change to Win as a response to that federation's ineffectiveness. This article concludes that the split may lead to new techniques for campaigning, but that it will not affect the fortunes or the social vision of the trade union movement.

The November 2004 re-election of George W. Bush brought the morale of the progressive camp in the US to a new low. Not only was Bush to remain president, but his level of support within the electorate had actually increased. Staff at several so-called 'organising unions' had issued proposals to reform the labour movement the previous year; and with the defeat of John Kerry, reform-minded union leaders now demanded the resignation of top leaders of the AFL-CIO [American Federation of Labor and Congress of Industrial Organizations]. When they failed to win majority support for their plan at the June 2005 convention, seven national unions, representing six million workers or forty per cent of AFL$\mathrm{ClO}$ affiliated union members, formed a new group, 'Change to Win', which held its founding convention in September 2005.

What does this split mean for the future of us unions? In this paper, I will argue that the new federation may create a more efficient organising apparatus, but that it will not push the unions' political programmes beyond business unionism.

\section{The debate}

Two main arguments exist in favour of Change to Win's position. First, that the new federation differs from the AFL-ClO in a crucial way: it has a more serious commitment to organising and restructuring. And second, that Change to Win will spread and develop the successful model of the Service Employees International Union (SEIU) to organise the growing service-sector workforce. The split, according to this line of reasoning, could help to reverse the decline of us unions.

Critics point out, however, that the debate around the split did not concern the goals of unions, or their agendas. The new federation's leaders have called for more labour-management cooperation and dismissed the value of union democracy, and communicate in a suspiciously slick way reminiscent of the Democratic Party and liberal advocacy groups. These critics have also noted that most of the worker groups represented by Change to Win unions have not experienced growth in membership density, and therefore cannot really be considered success stories. Change to Win's response to globalisation, they have argued, seems to be an attempt (at the national level, and usually unsuccessfully, it turns out) to 
build density in 'landlocked' sectors not yet plagued by capital flight.

A third position is that the creation of a new federation could backfire by undermining the solidarity built into the AFL-CIO’s unitary structure.

First, because with two smaller political machines instead of the single large one managed by the AFL-CIO, labour could be less influential in political campaigns. Second, some suggest that the split could lead to disaffiliations from countywide Central Labour Councils (CLCS) and state-level labour federations, which would disrupt local inter-union cooperation and reduce dues payments to sub-national union bodies. Third, many fear that jurisdictional battles could become more heated as unions fight over new potential organising targets, especially in the public sector, without the AFL-CIO to mediate disputes.

Who is right? On the one hand, the dissidents have a valid point: the split will not radicalise unions, at least not in a way that would affect their goals. Political action will remain important but, in keeping with the strategy of the SEIU and the carpenters' union, will remain instrumental to collective bargaining and organising. On the other hand, there is little evidence so far of the split backfiring. Mergers and the new federation will create larger and more centralised structures, which will probably be more streamlined and campaign- or project-focused. What we may see, therefore, is an improvement in the techniques of organising, without a change in agenda.

\section{The failure of organising}

1995 was supposed to be the beginning of a new era for us unions. That year, an attempt to reform federal labour law broke down in the face of the dramatic 1994 Republican victory in congressional elections. in the first serious contest for AFL-ClO leadership ever, several national union presidents blocked the incumbent's hand-picked successor and elected John Sweeney. Sweeney had been president of the SEIU, the fastest-growing union in the country, which was organising workers in janitorial services, healthcare and the public sector (as well as absorbing smaller unions in these areas). Since 1985, according to AFL-CIO statistics, the SEIU had expanded from less than 700,000 to more than a million members, not only through mergers but also through innovative strategies like the Justice for Janitors campaign, and a highly effective healthcare organising strategy. (The only other major union experiencing rapid growth at the time was the American Federation of Teachers.)

Once in power, Sweeney and his allies placed a new emphasis on organising, mainly by encouraging affiliates to reallocate their resources, but also by supporting individual organising campaigns and building organising capacity. Since the AFL-CIO has no ability to sanction its affiliates other than by expelling them, Sweeney emphasised 'consensus-building' in his approach to change. Highlights of Sweeney's first decade in office include:

1. The creation of new organs within the AFL-CIO in order to support organising. These include a Corporate Affairs Department to engage in shareholder activism, and the Organizing Institute, whose role is to recruit and train staff organisers;

2. The 'Union Summer' programme, which exposed hundreds of college students and young workers to organising 
work;

3. The 'Union Cities' programme, created to build organising capacity at the regional level;

4. Support for several major organising campaigns, including those of strawberry pickers in California, nursing-home workers in south Florida, construction workers in Las Vegas, airport workers in Los Angeles and San Francisco, maritime workers in south Louisiana, and many others;

5. Highly publicised tours through the country in order to support immigrant workers and laid-off Enron workers;

6. Mass mobilisations of members for internationally significant rallies in Seattle and Miami.

In terms of membership growth, the results were disappointing. Between 1995 and 2004, union density slipped from 14.9 per cent to 12.5 per cent, and union membership declined by around 900,000. Although a few unions began to grow, union density continued to decline in nearly every sector and occupation. The 'failure of organising' was common to both Change to Win and AFL-ClO affiliates, as Richard Hurd pointed out in his analysis of union density data since the late-1980s (WorkingUSA, September 2004). Membership and density decline occurred not only in industries and occupations dominated by unions that stayed in the AFL-CIO (such as in the manufacturing and communications industries), but also in industries mainly organised by breakaway unions, such as in retail trade and transportation. Unions on both sides of the split, in industries like construction, public administration and education, were growing along with the expanding workforce and the tightening labour market of the late-I990s. This, however, did not necessarily mean an increase in union density. In the strongholds of breakaway unions like construction and healthcare, density was declining despite an increase in membership. In other Change to Win areas such as retail trade, restaurants and janitorial work, unions were losing not only density but also absolute membership.

Because of this decline, unions failed to prevent gains by the conservative camp, including Republican victories in the presidential elections in both 2000 and 2004. This was not due to a lack of effort. From 1992 to 2000, the percentage of voters from union households increased from 19 per cent to 26 per cent of the electorate, despite the decline in union membership. The Republicans, however, were also quite effective in mobilising their base. The re-election of President Bush in 2004 demonstrated to insurgents and incumbents alike how ineffective the AFL-CIO had been in affecting the direction of American politics.

\section{The split}

In 2001, the United Brotherhood of Carpenters and Joiners of America (UBC)-a major union-left the AFL-CIO. The UBC's president, Doug McCarron, came to power in 1997 and immediately began to restructure the union. He pared down the staff at the union's headquarters from 250 to 18, largely through extensive outsourcing, and moved the central office out of downtown Washington DC. The union redeveloped its old headquarters in order to generate $820 \mathrm{~m}$ a year in rent, which could be used for organising, and shifted a wide range of responsibilities from more than a thousand townlevel local unions to much more centralised regional councils. He shifted half of the UBC's resources into organising and then, arguing that dues to the AFL-ClO were diverting resources away from organising, he pulled the union out of the 
federation. Along the way, McCarron made overtures to the Bush administration (inviting the president to two Labor Day picnics) and the business community, which gave him a reputation as a right-winger.

At the time, McCarron was seen as an anomaly in the labour movement: a weird mixture of conservative and proorganising currents. A group of national union presidents began meeting with McCarron, initially in order to convince him to reaffiliate, but eventually in order to devise a strategy to restructure the labour movement. In 2003, several national union presidents set up a reform group known as the New Unity Partnership (NUP), which included McCarron, the SEIU's Andy Stern (who had a reputation as a political progressive), and the leaders of three other soon-to-disaffiliate unions.

SEIU staff member Steven Lerner wrote the basic policy document of the NUP. In the most diplomatic terms possible, Lerner argued that Sweeney's attempt to promote organising had failed. It was not that the organising idea had failed to win adherents, but rather that too many unions were too small and too thinly spread over many industries to be able to build power effectively. As unions declined, employers with unionised employees were losing market share and becoming more antiunion under intensifying pressures to reduce costs. Lerner argued that unions should merge in a way that would conform to the boundaries of industries, sectors and labour markets.

Centralising power in a single organisation would not only give them a sharper strategic focus, but would also create economies of scale. Such an organisation could mobilise hundreds of full-time organisers, thousands of volunteer union members, tens of thousands of volunteers in unorganised workplaces, hundreds of thousands of community allies, tens of millions of dollars in dues money, and billions of dollars in union-controlled pension investments. Though he rejected the notion of disaffiliation from the AFL-CIO, Lerner called for the AFL-CIO to restructure its affiliates in ways that, he argued, would make them fit to confront powerful, anti-union corporations (New Labor Forum, June 2003).

The NUP-ers waited until the November 2004 election to make their move. Democratic candidate John Kerry lost, despite donations and voter turnout in unions from both sides of the new divide. The Change to Win Coalition (CWC) was formed in order to build support for reform at the AFL-CIO convention. Andy Stern became increasingly vocal in the public debate, and his criticisms of other unions elicited hostile responses from elsewhere in the labour movement, especially from beleaguered manufacturing unionists. The CWC released a series of proposals similar in spirit to Lerner's paper and with a few additions, including a dues rebate from the federation to national unions, to be used for new organising, an effort to bring more women and minorities into union leadership, a stronger international dimension to union work, a new campaign to reform the healthcare and pension systems, and-most controversially-new leadership for the federation. The AFL-CIO made a competing proposal whose chief differences seemed to be a smaller rebate, a voluntary approach to restructuring (rather than Lerner's mandatory 'strategic' approach), and no plan to unseat Sweeney.

On the eve of the June 2005 convention, when it became clear that the CWC lacked the support it needed to push through the reform concept, unions began to pull out of the AFL-CIO. On 27 September, the new confederation held its founding convention in St. Louis. Delegates from seven unions attended, representing around six million members .They decided on a new name ('Change to Win') and, in a single day, passed a founding set of principles. Change to Win would have a simple organisational structure with only three departments, and a yearly income of $8750 \mathrm{~m}, 75$ per cent of which 
would fund organising.

\section{The future}

Although the split is no longer in the news, it is still recent enough that no definitive assessment is possible. It seems, however, that the split has generated less antagonism and disrupted daily union work less than had been feared. (The internet blog Working Life, at <http://workinglife.typepad.com>, has paid especially close attention to these issues).

Much of the debate centred around the question of whether unions should receive a dues rebate for organising from an organisation devoted to politics, leading to speculation that the breakaway unions would deemphasise politics and focus on pure workforce concerns. However, in the 2005 state- level elections, unions effectively coordinated election work without common affiliation in the AFL-CIO. Since it was an odd-numbered year, with no federal races, the stakes were relatively low. In California, Change to Win's most important stronghold, Republican Governor Arnold Schwarzenegger proposed several ballot initiatives in the hope that the voters would approve laws blocked by the Democrat-led legislature. Two of the initiatives, one of which was to restrict the use of union dues for political campaigns and the other to weaken teachers' job-security protection, were directly aimed at public-sector unions. The conflict within the labour movement did not prevent unions from uniting in order to defeat Schwarzenegger's proposals; and unions could very well repeat this performance in the much higher stakes of the 2006 congressional elections.

Part of the reason for these successes is that the feared disorganisation at state and local levels seems not to be happening. After the split, Change to Win leaders such as Anna Burger, its chair, suggested that the new federation would encourage local unions to remain affiliated and to continue paying dues to local and state bodies. The AFL-CIO leadership responded with a proposal for 'Solidarity Charters'. Change to Win-affiliated locals would pay an additional ten-per-cent dues surcharge, and their officers would be ineligible to serve on the governing bodies of state and local bodies.

The AFL-CIO's demands led to widespread fears that key city and state- level labour leaders would have to step down due to the affiliation of their national unions, and to disaffiliate due to the surcharge. At the time of writing, the two federations announced that they had reached a compromise agreement involving some sort of a surcharge, and allowing officers of Change to Win affiliates to serve on state and local AFL-CIO boards. It remains unclear how many locals will disaffiliate, but the split seems unlikely to undermine cooperation between local unionists where it already exists.

Some observers worried that the split would signal open war over jurisdictions, especially in the public sector. In this most heavily organised of industries, the indications are hopeful. Two major public-sector unions, the SEIU and the American Federation of State, County and Municipal Employees (AFSCME, which stayed with the AFL-CIO), claim the public sector as their own. After the split they signed a national pact, which included not only a pledge not to decertify each other's bargaining units or interfere with each other's campaigns, but also the creation of a dispute- resolution procedure, a few jointly affiliated local unions, and a collaborative childcare organising campaign. This deal shows that these national unions are self-disciplined enough to be able to settle jurisdictional disputes without a common affiliation in the AFL-CIO.

This is not to say that the split will have no effect on union tactics and methods. The new and massive organising 
fund will create a space in which more sophisticated strategies can be developed, carried out by larger, more centralised unions.

We have already seen these techniques in recent mobilisations of popular outrage over Wal-Mart's employment practices and its effects on local economies, and over the Bush administration's handling of Hurricane Katrina. Internet and other media campaigns played important roles in these mobilisations, and it seems likely that this sophistication will translate into new organising techniques. The split, however, will not lead to an abandonment of the unions' highly instrumental approach to politics, and the breakaway unions will not propose socialism in America. Their agenda involves rebuilding the middle class and representing working families. They may be contentious at times, but these unions advocate constructive relations with employers and politicians.

Change to Win has both contentious and cooperative sides, and in this sense it hardly differs from the AFL-CIO. Both federations combine social-movement and business unionism, conservatism and progressivism, nationalism and internationalism. The difference is a technical and organisational one, rather than one of ideology or goals. The question now is whether this hybrid of business and social-movement unionism can function better outside the AFL-CIO. 